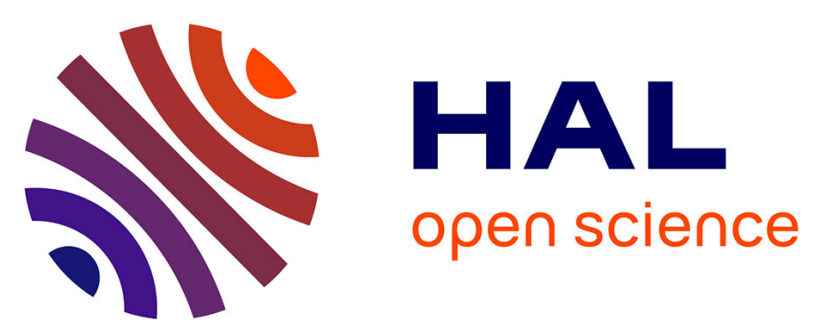

\title{
Elucidating cellular and behavioural effects of contaminant impact (Polycyclic aromatic hydrocarbons, PAHs) in both laboratory-exposed and field-collected shore crabs, Carcinus maenas (Crustacea: Decapoda)
} Awantha Dissanayake, Camilla Piggott, Christopher Baldwin, Katherine A. Sloman.

\section{To cite this version:}

Awantha Dissanayake, Camilla Piggott, Christopher Baldwin, Katherine A. Sloman.. Elucidating cellular and behavioural effects of contaminant impact (Polycyclic aromatic hydrocarbons, PAHs) in both laboratory-exposed and field-collected shore crabs, Carcinus maenas (Crustacea: Decapoda). Marine Environmental Research, 2010, 70 (5), pp.368. 10.1016/j.marenvres.2010.07.004 . hal-00631695

\author{
HAL Id: hal-00631695 \\ https://hal.science/hal-00631695
}

Submitted on 13 Oct 2011

HAL is a multi-disciplinary open access archive for the deposit and dissemination of scientific research documents, whether they are published or not. The documents may come from teaching and research institutions in France or abroad, or from public or private research centers.
L'archive ouverte pluridisciplinaire HAL, est destinée au dépôt et à la diffusion de documents scientifiques de niveau recherche, publiés ou non, émanant des établissements d'enseignement et de recherche français ou étrangers, des laboratoires publics ou privés. 


\section{Accepted Manuscript}

Title: Elucidating cellular and behavioural effects of contaminant impact (Polycyclic aromatic hydrocarbons, PAHs) in both laboratory-exposed and field-collected shore crabs, Carcinus maenas (Crustacea: Decapoda)

Authors: Awantha Dissanayake, Camilla Piggott, Christopher Baldwin, Katherine A.

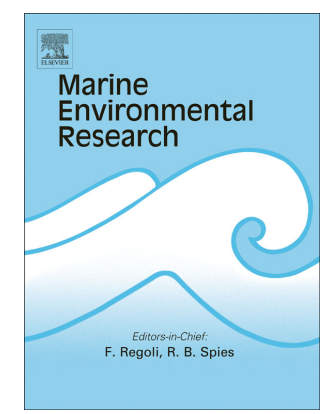
Sloman.

PII:

$$
\text { S0141-1136(10)00115-7 }
$$

DOI:

$$
\text { 10.1016/j.marenvres.2010.07.004 }
$$

Reference: MERE 3466

To appear in: Marine Environmental Research

Received Date: 24 May 2010

Revised Date: 19 July 2010

Accepted Date: 26 July 2010

Please cite this article as: Dissanayake, A., Piggott, C., Baldwin, C., Sloman., K.A. Elucidating cellular and behavioural effects of contaminant impact (Polycyclic aromatic hydrocarbons, PAHs) in both laboratory-exposed and field-collected shore crabs, Carcinus maenas (Crustacea: Decapoda), Marine Environmental Research (2010), doi: 10.1016/j.marenvres.2010.07.004

This is a PDF file of an unedited manuscript that has been accepted for publication. As a service to our customers we are providing this early version of the manuscript. The manuscript will undergo copyediting, typesetting, and review of the resulting proof before it is published in its final form. Please note that during the production process errors may be discovered which could affect the content, and all legal disclaimers that apply to the journal pertain. 
5

Elucidating cellular and behavioural effects of contaminant impact (Polycyclic aromatic hydrocarbons, PAHs) in both laboratory-exposed and field-collected shore crabs, Carcinus maenas (Crustacea: Decapoda).

10 Awantha Dissanayake ${ }^{* 1}$ Camilla Piggott $^{2}$, Christopher Baldwin ${ }^{2}$, Katherine A. Sloman ${ }^{2}$.

${ }^{1}$ Institute for East China Sea Research, Nagasaki University, Taira-machi 1551-7, Nagasaki 851-2213, Japan.

${ }^{2}$ School of Marine Science and Engineering, University of Plymouth, Drake Circus, Plymouth, PL4 8AA, U.K.

*Corresponding author.

Email: awantha@ nagasaki-u.ac.jp 


\section{ABSTRACT}

Monitoring effects of contaminants at lower levels of biological organisation (e.g. biochemical and cellular) allows for mechanistic evaluation of effects of contaminant exposure through laboratory exposures. However, higher level organism effects (e.g.

physiological and behavioural) are deemed more ecologically-relevant. In the present study, cellular (cell viability and immune function), physiological (cardiac activity) and behavioural (foraging behaviour) responses were evaluated in field-collected shore crabs Carcinus maenas from three estuaries [a 'relatively' (polycyclic aromatic hydrocarbon) $\mathrm{PAH}-$ contaminated site (Plym Estuary) and two ‘comparatively clean' field sites (Avon and Yealm

Estuaries)] and compared with responses of crabs exposed in the laboratory to a model organic contaminant (PAH) pyrene $\left(200 \mu \mathrm{gl}^{-1}\right.$ for 28 days). The hypothesis that behavioural indicators may be more sensitive than other more traditional methods was tested. No significant impacts were observed at the cellular or physiological level in Plym-collected crabs (the 'relatively' contaminated site), but foraging behaviour was significantly altered (increased prey handling time) compared to individuals collected from the 'relatively' uncontaminated sites (Avon and Yealm). When given a cockle as a prey item, both Plymcollected and laboratory-exposed crabs took longer to handle and break into cockle shells. Therefore, ecologically-relevant behavioural observations may serve as valuable indicators of environmental quality.

Keywords: Carcinus maenas, PAH, pyrene, behaviour, physiology 


\section{INTRODUCTION}

50 Environmental contaminants, such as polyaromatic hydrocarbons (PAHs), are ubiquitous pollutants in the aquatic environment and pose a serious risk to aquatic organisms (Blaxter \& Ten Hallers 1992; OSPAR 2001). PAHs are a group of chemical compounds, containing two or more fused benzene rings, which are highly lipophilic ( $\left.\log \mathrm{K}_{\mathrm{ow}}=3-8\right)$ (Readman et al., 2002). In the marine environment, PAHs are a product of incomplete combustion processes and petrochemical pollution from anthropogenic sources, such as boat traffic which contributes to high concentrations of fuel in water systems and sediment (King et al., 2004). Examples of PAHs include pyrene, a 4-ringed PAH that is included in the priority pollutant list (OSPAR 2001). The toxic effect of contaminants, including PAHs, originates from chemical processes at the molecular level when the contaminant impact exceeds the effects of compensatory physiological responses; effects are expressed through the hierarchical levels of biological organisation i.e. biochemical, cellular and physiological levels (Fossi et al., 1994). Polyaromatic hydrocarbons, such as pyrene, cause physiological impairments such as DNA damage leading to neoplasia in fish (van der Oost et al., 1994; Aas et al., 2000), and alteration of cellular function (viability and immune function) in various invertebrate species, such as bivalves (Lowe et al., 1995; Grundy et al., 1996a; Lowe \& Fossato 2000) and decapod crustaceans (Dissanayake et al., 2008a; 2008b).

The shore crab Carcinus maenas, is a common crab species found along European shores and estuaries (Hunter \& Naylor 1993; Hayward \& Ryland 1995) The shore crab Carcinus maenas, is a common crab species found along European shores and estuaries (Hunter and Naylor, 1993; Hayward and Ryland, 1995) and may be exposed to PAHs both by waterborne (through the gills) and trophic (feeding) exposure as it is a durophagous predator (Crothers 
1968). Predicting impacts of anthropogenic activities and the consequences for marine organisms is essential if we are to conserve species diversity. Changes in organism functions, including behavioural and physiological alterations, facilitate monitoring of contaminant effects (Galloway et al., 2004; 2006). In particular, behavioural indicators may provide a particularly sensitive insight into various levels of molecular, physiological, and ecological aspects of toxicology by providing ecological relevance to routine physiological measures of toxicity (McGaw et al., 1999; Scott \& Sloman 2004). Laboratory studies allow for mechanistic understanding of effects of contaminant exposure at lower levels of biological organisation (i.e. biochemical and cellular) (Dam et al., 2006; Dissanayake et al., 2008a; 2009; Scarlett et al., 2009), however, when compared with behavioural indicators, physiological assessments may not be sensitive enough to signal effects of environmentallyrealistic contaminant exposure in field-collected organisms. The aim of this study was therefore to assess potential physiological and behavioural effects of both laboratory and field exposure to PAH (pyrene) in the shore crab, Carcinus maenas. To achieve this aim, cellular, physiological and behavioural endpoints were measured in crabs collected from three field sites [a 'relatively' PAH contaminated site (Plym Estuary) and two 'comparatively clean' field sites (Avon and Yealm Estuaries)] and compared with responses of laboratory-exposed pyrene $\left(200 \mu \mathrm{g}^{-1}\right.$ for 28 days $)$.

\section{METHODS}

\subsection{Collection and maintenance of animals}

Intermoult adult male Carcinus maenas $(66.3 \pm 5.07 \mathrm{~mm})$ were collected using mackerelbaited traps from three estuaries in South-West England (Fig. 1): the Avon Estuary, Bantham 
$\left(50^{\circ} 16^{\prime} 42 \mathrm{~N}, 3^{\circ} 52^{\prime} 18 \mathrm{~W}\right)$, the Yealm Estuary, Newton Ferrers $\left(50^{\circ} 18^{\prime} 49 \mathrm{~N}, 4^{\circ} 03^{\prime} 08 \mathrm{~W}\right)$, and the Plym Estuary, Sutton Harbour (50 $21^{\prime} 54$ N, $\left.4^{\circ} 08^{\prime} 02 \mathrm{~W}\right)$. There is an apparent lack of data concerning environmental quality with reference to specific types of contaminants i.e.

PAHs; PAH metabolites, however, have been shown to be a useful surrogate indicator of PAH contamination in field sites (Galloway et al., 2004). Pyrene levels can be indicative of PAH contamination (4-ringed PAHs) e.g. 17-20 $\mu \mathrm{g} 1-1$ is indicative of relatively clean coastal sites and > 40 indicative of PAH- contaminated sites; > $200 \mu \mathrm{g} 1-1$ has been recorded in coastal harbour sites (Dissanayake \& Bamber 2010). Based on this lack of knowledge, sites were ranked based on the degree of maritime activity (thus PAH contamination). The Avon Estuary receives $<20$ vessels $\mathrm{yr}^{-1}$ (QHM 2006a, personal communication), has low levels of contamination (Hagger et al., 2008) and is regarded as 'not at risk' from both point source and diffuse pollution (Environment Agency 1996); the Yealm Estuary supports < 250 vessels $\mathrm{yr}^{-1}$ (QHM 2006c, personal communication), has low levels of contamination (Hagger et al.,

110 2008). In contrast, the Plym Estuary receives > 1500 vessels $\mathrm{yr}^{-1}$ (QHM 2006b, personal communication). The influence of other contaminants cannot be ruled out in field-exposed crabs as the presence of copper and tributyltin (TBT), a component of antifouling paint has been found previously in both the Yealm and Plym Estuaries and have been listed as 'at risk' from diffuse pollution (Environment Agency 2006) (for details see Environment Agency 1996; Scarlett et al., 1997; Scarlett et al., 1999) and is linked with maritime activity.

The experimental series consisted of two parts. In the first experiment, crabs were exposed to $\mathrm{PAH}$ contamination in the laboratory and cellular, physiological and behavioural measurements were made at the end of this time $(n=9)$. In the second experiment, crabs were collected from the three field sites $(n=9$ individuals from each site) and cellular, physiological and behavioural measurements were performed soon after collection (see 
below). During the first experiment, Carcinus maenas individuals collected from the Avon Estuary (a 'comparatively' clean site) were exposed individually to $200 \mu \mathrm{g} \mathrm{l}^{-1}$ pyrene (nominal concentration) [a known sublethal concentration that induces sublethal physiological and behavioural effects in several invertebrate species (Christensen et al., 2002; Dissanayake et al., 2008a; 2009) or placed into clean filtered (10 $\mu \mathrm{m}$ carbon-filtered) aerated seawater (salinity of $34,15 \pm 1{ }^{\circ} \mathrm{C}$ ) under a $12 \mathrm{~h}$ light: $12 \mathrm{~h}$ dark photoperiod (control) $(n=9$ per treatment). Solvent used to prepare the pyrene exposure water (acetone, $0.005 \%$ ) does not contribute to PAH metabolite fluorescence or cause any negative effects on cellular or behavioural parameters as shown previously(Dissanayake et al., 2008b). Crabs were held in the laboratory for two weeks prior to the exposure to acclimate to laboratory conditions. During the 28 day exposure, crabs were fed individually on $1 \mathrm{~g}$ of $\gamma$-irradiated cockle (Cerastoderma edule, Tropical Marine Centre, Bristol, UK) flesh every two days. Water was changed within $18 \mathrm{~h}$ of feeding. At the end of the 28 day period, crabs were sampled in the same way as field-collected crabs (see below).

\section{2. $\quad$ Sampling Procedure}

Within $24 \mathrm{~h}$ of the end of the laboratory exposure or field collection, crabs were sampled ( $n=9$ per treatment) for urine to determine the presence of PAH metabolites. After a further $24 \mathrm{~h}$, haemolymph was sampled from the same crabs for cellular assays. Physiological assessments (heart rate) and behavioural observations were performed on these individuals following a $72 \mathrm{~h}$ starvation period [to standardise hunger levels and induce feeding behaviour (Thorpe et al., 1995; Rovero et al., 2000; Smallegange \& Van der Meer 2003)]. Urine and haemolymph sampling techniques are non-destructive. The periods between sampling the same individual for different physiological and behavioural parameters have been shown to 
allow sufficient recovery in previous studies (Bamber \& Depledge 1997a; 1997b). Heart rate levels, for example, have been observed to decrease from 'active' (i.e. handling stress) to 'resting' levels within 30 min (Dissanayake et al., 2008b). During periods between sampling, crabs were kept in static holding tanks containing filtered seawater. At the end of the experiment crabs were held for a further two weeks to ensure that they were not in proecdysis, which could potentially affect physiological condition and behaviour.

\subsection{Urine sampling and analysis}

To collect urine samples, crabs were restrained on a board with the third maxillipeds separated. Urine was collected using a $1 \mathrm{ml}$ syringe with an attached $10 \mu 1$ micropipette tip by prising open each opercula of the antennal gland (Bamber \& Naylor 1997). Urine samples were stored at $-20{ }^{\circ} \mathrm{C}$ prior to analysis, when as a surrogate indicator of contaminant exposure, pyrene metabolites in urine were determined by fluorescence analysis $\left(\lambda_{345 / 382}\right.$; BIOTEK FL600) for 1-hydroxylpyrene-type metabolites (Dissanayake \& Galloway 2004; Watson 2004). Urine sample were diluted with $50 \%$ ethanol (ratio 1:20).

\subsection{Haemolymph sampling and analysis}

Haemolymph samples $(500 \mu \mathrm{l})$ from individual crabs were extracted by puncture of the arthrodial membrane at the base of the $4^{\text {th }}$ walking leg using an ice-chilled $1 \mathrm{ml}$ syringe and 21 gauge needle (Sigma-Aldrich, U.K). Cellular techniques were conducted immediately after haemolymph sampling. Cellular viability was determined in vitro using the microplate neutral red dye uptake method of Babich and Borenfreund (1991), whereby, incorporation of the dye within the lysosomes of cells indicates viable cells, whereas decreased uptake and 
dye retention indicates dead or damaged cells. Neutral red solution $(200 \mu 1 ; 0.004 \%)$ was added to haemolymph samples $(30 \mu \mathrm{l})$ in microtitreplates. After $3 \mathrm{~h}$ incubation $\left(10^{\circ} \mathrm{C}\right)$, cells were washed using phosphate buffered saline (phosphate buffer $0.01 \mathrm{M}, \mathrm{KCl} 0.0027 \mathrm{M}, \mathrm{NaCl}$ $0.137 \mathrm{M})$ and lysed with $1 \%$ acidified ethanol solution (1\% acetic acid/ $50 \%$ ethanol). Residual dye was determined spectrophotometrically at $550 \mathrm{~nm}$ (Galloway et al., 2004). The phagocytic capability of haemocytes was evaluated by measuring the active uptake of neutral red-stained zymosan particles (from Saccharomyces cerevisiae, Sigma, U.K) in vitro. Haemolymph samples $(30 \mu \mathrm{l})$ were incubated $\left(10^{\circ} \mathrm{C}\right.$ for $\left.30 \mathrm{~min}\right)$ with dye-stained particles $\left(1 \times 10^{8}\right.$ particles $\left.\mathrm{ml}^{-1}\right)$ and washed using phosphate buffered saline to remove excess particles. Cells were lysed with $1 \%$ acidified ethanol solution and the amount of particles taken up was determined spectrophotometrically at $550 \mathrm{~nm}$ as described by Parry and Pipe (2004), and employed by Dissanayake et al.(2008b; 2008a).

\subsection{Foraging behaviour and heart rate monitoring}

Prior to measuring foraging behaviour, individuals were starved for $72 \mathrm{~h}$ in order to standardise hunger levels. All tanks were oxygenated for 10 min prior to the addition of test individuals. Dissolved Oxygen (D.O.) levels were measured at the start (120-130\%) and end (112-120\%) of each trial to ensure that individuals were not exposed to hypoxic conditions. Cardiac activity was recorded using an infrared phototransducer attached to the carapace using cyanoacrylate glue to facilitate heart rate monitoring using the ComputerAided Physiological MONitoring system (CAPMON) (Depledge \& Andersen 1990). Once the phototransducer had been attached to the carapace, individuals were placed in one end of an observation chamber $[L x H x W=46 \times 25 \times 25(\mathrm{~cm})]$ and given five minutes acclimation time. Cardiac activity was then recorded to obtain basal heart rate. The chamber was blacked out on three sides to limit external visual stimuli. A whole cockle within its shell $(0.35 \pm 0.05 \mathrm{~g})$ [weight class readily accepted by adult shore crabs) (Mascaro \& Seed 2001) 
and abundant prey item at all tested field sites] was placed in the opposite end of the chamber, separated from the crab by a vertically sliding blackened glass divider. Foraging behaviour and cardiac activity was then observed and recorded for 15 min when the divider was raised. Foraging activity and cardiac activity was recorded for $15 \mathrm{~min}$ as this time period allowed sufficient time to record both activities; consumed food passes from the oesophagus to the stomach region within 15 minutes and any further recording of cardiac activity (i.e. past 15 min) may result in elevated heart rates associated with digestion and the specific dynamic action of food (Houlihan et al., 1990; McGaw \& Reiber 2000). A video camera (Canon MV830) was used to record behaviour. Foraging behaviour was divided into a series of behaviours that encompass prey search, prey handling and prey consumption, quantified by direct observation and recording of the following behavioural categories (Rovero et al., 2000;

Smallegange \& Van der Meer 2003).

$$
T_{h}(s)=T_{b}(s)+T_{e}(s)
$$

Breaking time $\left(T_{b}\right)=$ time taken from individual's first attempt to open cockle, to first consumption of flesh.

Eating time $\left(T_{e}\right)=$ time taken for crab to consume cockle flesh and discard shell.

210 Handling time $\left(T_{h}\right)=$ Sum of both breaking time and eating time.

\subsection{Statistical analysis}

One-way Analysis of variance tests (ANOVA) were performed on the chemical (PAH metabolites) and biological (cellular viability, immune function and series of foraging 215 behaviour measurements) endpoints (transformed where necessary to meet parametric assumptions) (GMAV 5 for Windows $\left.{ }^{\circledR}\right)$ (Underwood 2005); Student-Newman-Keuls (SNK) 
tests were used to isolate differences between experimental groups (field-collected and laboratory-exposed crabs).

\section{RESULTS}

220 Significant differences were observed between experimental groups, with the highest metabolite concentrations observed in urine of laboratory pyrene-exposed crabs and Plymcollected crabs (square root-transformed; $\mathrm{F}_{4,40}=13.82, P<0.001$, Fig. 2). Evaluation of potential contaminant effects at the cellular level in crab haemocytes, revealed significantly lower cellular viability (square root-transformed $\mathrm{F}_{4,40}=4.91, P<0.01$, Fig. 3A) and

225 phagocytosis $\left(\mathrm{F}_{4,40}=3.17, P<0.01\right.$, Fig. 3B) in laboratory-exposed crabs. With regard to foraging behavior, Plym Estuary-collected crabs had significantly higher breaking times compared to all other groups $\left(\mathrm{F}_{4,40}=3.64, P<0.05\right.$; Fig $\left.4 \mathrm{~A}\right)$. Significant differences in handling time were observed between groups, with Plym Estuary-collected crabs and laboratory pyrene-exposed crabs displaying longer prey handling times compared to all other groups of crabs $\left(\mathrm{F}_{4,40}=2.83, P<0.05\right.$; Fig. $\left.4 \mathrm{C}\right)$. No significant differences were observed in eating time between shore crabs from each of the treatment groups (log-transformed $\mathrm{F}_{4,40}=1.23, P=0.31 ;$ Fig. 4B). Physiological monitoring demonstrated that Avon-collected crabs displayed significantly lower heart rates while handling prey than crabs from all the other treatments (square root-transformed; $\mathrm{F}_{4,40}=8.03, P<0.001$, Fig. 4D).

\section{DISCUSSION}

This study compared the sensitivity of cellular, physiological and behavioural measures using a combination of laboratory-exposed and field-collected shore crabs. Contaminant exposure was validated by spectrofluorimetric determination of pyrene-type metabolites in C. maenas 
urine with the highest concentrations observed in laboratory pyrene-exposed crabs and Plym Estuary-collected crabs. Although PAH levels (pyrene) were not fully quantified, a screening method for pyrene metabolites was used as a surrogate indicator of the bioavailable pyrene levels at each site and can be used to discern between sites of varying PAH exposure (Dissanayake \& Galloway 2004). Pyrene metabolite levels measured in urine from the 245 laboratory-exposed crabs were consistent with levels previously reported for $200 \mu \mathrm{g} \mathrm{L}{ }^{-1}$ pyrene-exposed crabs (Watson et al., 2004; Dissanayake et al., 2008a; 2008b). Pyrene metabolite levels measured in crabs from the Plym Estuary were (on average) $30 \%$ less than those found in laboratory-exposed individuals and, therefore, may equate to exposures of approximately $67 \mu \mathrm{g} \mathrm{l}^{-1}$ of pyrene. Pyrene metabolite concentrations found in the Plym

250 Estuary-collected and laboratory-exposed crabs are consistent with levels reported previously in coastal waters (Law et al., 1997; Kirby et al., 1998; Woodhead et al., 1999), and within organisms [shore crabs (Watson et al., 2004) and in eels Anguilla Anguilla (Ruddock et al., 2003)] that are known to result in physiological impairment, such as alteration in antioxidant levels, altered cellular function (viability and immune function), elevated heart rates and decreased oxygen consumption (Fossi et al., 2000; Dissanayake et al., 2008a; 2008b).

Impacts at the cellular level were evaluated in shore crab haemocytes by assessing membrane integrity (cellular viability) and immune function (phagocytosis) which were negatively impacted (decreased cellular viability and phagocytosis) by contaminant exposure. However, only those crabs exposed to pyrene during lab exposures showed significant decreases in cellular viability and phagocytosis index. In C. maenas, lysosomes are found within the hyaline cells which are important in terms of phagocytic activity (the innate immune function in crustaceans) (Ratcliffe \& Rowley 1979). There are ca. $2.5 \times 10^{8}$ circulating haemocytes in C. maenas, and around $80 \%$ of these cells are capable of phagocytosis, thereby underscoring 
the phagocytic ability of this species (Smith \& Ratcliffe 1978). Pyrene is biotransformed by shore crabs into more hydrophilic compounds for excretion by phase I metabolism (Dam et al., 2006), however, PAHs exert their toxic effect by either the parent compound or subsequently, during metabolism resulting in production of reactive oxygen species (ROS) (Livingstone 1991; 1998). Resulting toxic effects in shore crab haemocytes include, membrane destabilisation and immune function alteration (Dissanayake et al., 2008a; 2008b).

Although, significant impact at the cellular level was only observed in laboratory pyreneexposed individuals, it provides an insight into the mechanism of acute contaminant exposure. Pyrene, like other PAHs which are polar hydrophobic contaminants, are sequestered in the lysosomal compartment of cells. Lysosomal damage arising from the accumulation of contaminants and formation of oxyradicals causes increased membrane permeability and subsequent release of acid hydrolases into the cytoplasm, resulting in cellular damage/cell death (as shown by decreased cellular viability) and, subsequently, resulting in a reduced immune function (as shown by reduced phagocytic ability) (Lowe et al., 1995; Grundy et al., 1996a; 1996b).

To assess behavioural impacts, foraging behaviour was divided into two behavioural components; breaking time and eating time. Significant differences were observed in breaking time, with Plym Estuary-collected crabs taking significantly longer than other fieldcollected and laboratory-exposed crabs to approach the cockle and break into the shell, thereby, exposing the flesh (i.e. possibly due to problems in orientating and breaking the shell). No significant differences were observed, however, in the time required to consume the prey (eating time). This resulted in differences in overall prey handling time with both PAH-contaminated groups of shore crabs (Plym Estuary-collected and laboratory pyreneexposed) displaying significantly longer handling times, corroborating previous findings of 
increased prey handling times in shore crabs fed with hydrocarbon-exposed mussels (mean tissue concentration of approximately $50 \mu \mathrm{g} / \mathrm{g}$ dry weight; (Scarlett et al., 2009). In terms of physiological disturbance (assessed here as cardiac activity), no difference was observed in cardiac activity between contaminant-exposed or field-collected crabs, except for Avoncollected crabs displaying significantly lower heart rates. Cardiac activity measurement was chosen as a surrogate indicator of the metabolic costing to the individual as a result of foraging behaviour. It is not clear why Avon-collected crabs displayed this lower heart rate, but based on measured PAH metabolites in the urine, there is no evidence that it is linked to the presence or absence of PAH contamination. To standardise foraging behaviour, crabs from all treatments were starved for a period of $72 \mathrm{~h}$ in clean water. Therefore, it is possible that behavioural effects of PAHs in the present study were underestimated with these concentrations of PAH possibly exerting much greater effects immediately after exposure.

Hydrocarbon contaminant exposure disrupts various behaviours in crustaceans such as mate search behaviour in amphipods (Krang 2007) and locomotor and agonistic behaviour in decapods (Pearson \& Olla 1990; Culbertson et al., 2007; Dissanayake et al., 2009). Here, water-borne contaminant exposure resulted in disruption of foraging behaviour in Carcinus maenas, contributing to existing evidence of behavioural disruption reported previously in this species (Dissanayake et al., 2009; Scarlett et al., 2009). As marine coastal environments continually receive anthropogenic inputs that are potentially toxic to aquatic organisms

310 (Galloway et al., 2006), it is imperative to measure appropriate biological endpoints that signal long-term ecological consequences (Hebel et al., 1997). Behavioural measures have been advocated as a subtle approach to potentially link physiological function of the individual (internal biological processes) with important ecological processes (Hebel et al., 1997; McGaw et al., 1999; Scott \& Sloman 2004). Foraging behaviour as an indicator of 
315 environmental quality has been employed successfully in fish, as observed by prey capture rates of shrimp by mummichogs (Fundulus heteroclitus). Fish from contaminated sites generally had significantly higher contaminant body burdens and lower prey capture rates compared to individuals from comparatively uncontaminated sites (Weis et al., 2001). Previous laboratory studies have shown perturbed behaviours (e.g. decreased feeding rates)

320 resulting from contaminant exposure (reviewed in Maltby 1999), and when feeding rate is considered in field studies it can significantly reflect environmental quality and contamination, as shown in various invertebrates, including decapods (Moreira et al., 2006a; 2006b; Culbertson et al., 2007). While laboratory exposures may help elucidate the mechanisms of contaminant-mediated toxicity by allowing detection of cellular and 325 physiological impacts, by incorporating behavioural measures, in addition to cellular techniques, thereby allows for a more holistic, ecologically-relevant determination of contaminant impact when determining effects in field-exposed animals. Disruption of important behaviours in this common estuarine and marine organism will, ultimately, have potential knock-on implications for the fitness and survival of the individual. Therefore,

330 studies considering the effects of contaminants across the breadth of biological organisation utilising both laboratory and field exposures are necessary to truly determine the effects of anthropogenic inputs on marine ecosystems.

\section{REFERENCES}

Aas E., Baussant T., Balk L., Liewenborg B., Andersen O.K. (2000). PAH metabolites in bile, cytochrome P4501A and DNA adducts as environmental risk parameters for chronic oil exposure: a laboratory experiment with Atlantic cod. Aquatic Toxicology 51, 241-258.

Babich H., Borenfreund E. (1991). Cytotoxicity of T-2 toxin and its metabolites determined with the neutral red cell viability assay. Appl Environ Microb 57, 2101-2103.

Bamber S.D., Depledge M.H. (1997a). Evaluation of changes in the adaptive physiology of shore crabs (Carcinus maenas) as an indicator of pollution in estuarine environments. Marine Biology 129, 667-672. 
Bamber S.D., Depledge M.H. (1997b). Responses of shore crabs to physiological challenges following exposure to selected environmental contaminants. Aquatic Toxicology 40, 79-92.

Bamber S.D., Naylor E. (1997). Sites of release of putative sex pheromone and sexual behaviour in female Carcinus maenas (Crustacea: Decapoda). Estuarine, Coastal and Shelf Science 44, 195-202.

Blaxter J.H.S., Ten Hallers C.C. (1992). The effect of pollutants on sensory systems and behaviour of aquatic animals. Neth J Aquatic Ecol 26, 43-58.

Christensen M., Andersen O., Banta G.T. (2002). Metabolism of pyrene by the polychaetes Nereis diversicolor and Arenicola marina. Aquatic Toxicology 58, 15-25.

Crothers J.H. (1968). The biology of the shore crab Carcinus maenas (L). 2. The life of the adult crab. Field Studies 2, 579-614.

Culbertson J.B., Valiela I., Peacock E.E., Reddy C.M., Carter A., VanderKruik R. (2007). Long-term biological effects of petroleum residues on fiddler crabs in salt marshes. Marine Pollution Bulletin 54, 955-962.

Dam E., Styrishave B., Rewitz K.F., Andersen O. (2006). Intermoult duration affects the susceptibility of shore crabs Carcinus maenas (L.) to pyrene and their ability to metabolise it. Aquatic Toxicology 80, 290-297.

Depledge M.H., Andersen B.B. (1990). A computer-aided physiological monitoring-system for continuous, long-term recording of cardiac activity in selected invertebrates. Comparative Biochemistry and Physiology a-Physiology 96, 473-477.

Dissanayake A., Bamber S.D. (2010). Detecting polyaromatic hydrocarbon (PAH) exposure in the Bay of Gibraltar, using fluorescence spectrophotometry as a biomonitoring tool of environmental contamination. Marine Environmental Research 70, 65-72.

Dissanayake A., Galloway T.S. (2004). Evaluation of fixed wavelength fluorescence and synchronous fluorescence spectrophotometry as a biomonitoring tool of environmental contamination. Marine Environmental Research 58, 281-285.

370 Dissanayake A., Galloway T.S., Jones M.B. (2008a). Nutritional status of Carcinus maenas (Crustacea: Decapoda) influences susceptibility to contaminant exposure. Aquatic Toxicology $89,40-46$.

Dissanayake A., Galloway T.S., Jones M.B. (2008b). Physiological responses of juvenile and adult shore crabs Carcinus maenas (Crustacea: Decapoda) to pyrene exposure. Marine

375 Environmental Research 66, 445-450.

Dissanayake A., Galloway T.S., Jones M.B. (2009). Physiological condition and intraspecific agonistic behaviour in Carcinus maenas (Crustacea: Decapoda). Journal of Experimental Marine Biology and Ecology 375, 57-63.

Environment Agency (1996). Local environment agency plan, Tamar estuary and tributaries. 97 pp.

Environment Agency (2006). Water Framework Directive - Risk Assessment. http://www.environment-agency.gov.uk/subjects/waterquality/?lang1/4_e (accessed online 19/09/2006).

Fossi M.C., Casini S., Savelli C., Corbelli C., Franchi E., Mattei N., Sanchez-Hernandez J.C., Corsi I., Bamber S., Depledge M.H. (2000). Biomarker responses at different levels of biological organisation in crabs (Carcinus aestuarii) experimentally exposed to benzo(alpha)pyrene. Chemosphere 40, 861-874.

Fossi M.C., Leonzio C., Peakall D.B. (1994) The use of nondestructive biomarkers in the hazard assessments of vertebrate populations. In: Fossi MC, Leonzio C (eds) Non -destructive Biomarkers in Vertebrates. Lewis Publishers, Boca Raton, Florida., p 3-34.

390 Galloway T.S., Brown R.J., Browne M.A., Dissanayake A., Lowe D., Depledge M.H., Jones M.B. (2006). The ECOMAN project: A novel approach to defining sustainable ecosystem function. Marine Pollution Bulletin 53, 186-194.

Galloway T.S., Brown R.J., Browne M.A., Dissanayake A., Lowe D., Jones M.B., Depledge M.H. (2004). A multibiomarker approach to environmental assessment. Environmental Science \& Technology 38, 1723-1731.

Grundy M.M., Moore M.N., Howell S.M., Ratcliffe N.A. (1996a). Phagocytic reduction and effects on lysosomal membranes by polycyclic aromatic hydrocarbons, in haemocytes of Mytilus edulis. Aquatic Toxicology 34, 273-290. 
Grundy M.M., Ratcliffe N.A., Moore M.N. (1996b). Immune inhibition in marine mussels by polycyclic aromatic hydrocarbons. Marine Environmental Research 42, 187-190.

Hagger J.A., Jones M.B., Lowe D., Leonard D.R.P., Owen R., Galloway T.S. (2008). Application of biomarkers for improving risk assessments of chemicals under the Water Framework Directive: A case study. Marine Pollution Bulletin 56, 1111-1118.

Hayward P.J., Ryland J.S. (1995) The marine fauna of the British Isles \& North-west Europe., Vol Vol. 1. Cambridge University Press. Cambridge

Hebel D.K., Jones M.B., Depledge M.H. (1997). Responses of crustaceans to contaminant exposure: A holistic approach. Estuarine Coastal and Shelf Science 44, 177-184.

Houlihan D.F., Waring C.P., Mathers E., Gray C. (1990). Protein synthesis and oxygen consumption of the shore crab Carcinus maenas after a meal. Physiological Zoology 63, 735-756.

410 Hunter E., Naylor E. (1993). Intertidal migration by the shore crab Carcinus maenas. Marine Ecology Progress Series 101, 131-138.

King A.J., Readman J.W., Zhou J.L. (2004). Dynamic behaviour of polycyclic aromatic hydrocarbons in Brighton marina, UK. Marine Pollution Bulletin 48, 229-239.

Kirby M.F., Blackburn M.A., Thain J.E., Waldock M.J. (1998). Assessment of water quality in estuarine and coastal waters of England and Wales using a contaminant concentration technique. Marine Pollution Bulletin 36, 631-642.

Krang A.-S. (2007). Naphthalene disrupts pheromone induced mate search in the amphipod Corophium volutator (Pallas). Aquatic Toxicology 85, 9-18.

Law R.J., Dawes V.J., Woodhead R.J., Matthiessen P. (1997). Polycyclic aromatic hydrocarbons (PAH) in seawater around England and Wales. Marine Pollution Bulletin 34, 306-322.

Livingstone D.R. (1991) Organic xenobiotic metabolism in marine invertebrates. In: Gilles R (ed) Advances in Comparative and Environmental Physiology, Vol 7. Springer-Verlag, Berlin, $p$ 46-185.

Livingstone D.R. (1998). The fate of organic xenobiotics in aquatic ecosystems: quantitative and qualitative differences in biotransformation by invertebrates and fish. Comp Biochem Phys A 120, 43-49.

Lowe D.M., Fossato V.U. (2000). The influence of environmental contaminants on lysosomal activity in the digestive cells of mussels (Mytilus galloprovincialis) from the Venice Lagoon. Aquatic Toxicology 48, 75-85.

430 Lowe D.M., Fossato V.U., Depledge M.H. (1995). Contaminant-induced lysosomal membrane damage in blood cells of mussels Mytilus galloprovincialis from the Venice Lagoon: An in vitro study. Marine Ecology-Progress Series 129, 189-196.

Maltby L. (1999). Studying stress: The importance of organism-level responses. Ecological Applications 9, 431-440.

435 Mascaro M., Seed R. (2001). Choice of prey size and species in Carcinus maenas (L.) feeding on four bivalves of contrasting shell morphology. Hydrobiologia 449, 159-170.

McGaw I., Reiber C. (2000). Integrated physiological responses to feeding in the blue crab Callinectes sapidus. Journal of Experimental Biology 203, 359-368.

$440 \quad$ salinity. Biological Bulletin 196, 163-176.

Moreira S.M., Lima I., Ribeiro R., Guilhermino L. (2006a). Effects of estuarine sediment contamination on feeding and on key physiological functions of the polychaete Hediste diversicolor: Laboratory and in situ assays. Aquatic Toxicology 78, 186-201.

Moreira S.M., Moreira-Santos M., Guilhermino L., Ribeiro R. (2006b). An in situ postexposure feeding assay with Carcinus maenas for estuarine sediment-overlying water toxicity evaluations. Environmental Pollution 139, 318-329.

OSPAR (2001) Polyaromatic hydrocarbons, OSPAR Commission

Parry H.E., Pipe R.K. (2004). Interactive effects of temperature and copper on immunocompetence and disease susceptibility in mussels (Mytilus edulis). Aquatic Toxicology 69, 311-325.

450 Pearson W.H., Olla B.O. (1990). Threshold for detection of naphthalene and other behavioural responses by the blue crab Callinectes sapidus. Estuaries 3, 224-229.

QHM (2006a) Queens Harbour Master (R. Avon)

QHM (2006b) Queens Harbour Master (R. Plym). www.rncom.mod.uk 
QHM (2006c) Queens Harbour Master (R. Yealm)

Ratcliffe N.A., Rowley A.F. (1979). A comparative synopsis of the structure and function of the blood cells of insects and invertebrates. Developmental \& Comparative Immunology 3, 189-243.

Readman J.W., Fillmann G., Tolosa I., Bartocci J., Villeneuve J.P., Catinni C., Mee L.D. (2002). Petroleum and PAH contamination of the Black Sea. Marine Pollution Bulletin 44, 48-62.

Rovero F., Hughes R.N., Chelazzi G. (2000). When time is of the essence: choosing a currency for prey-handling costs. Journal of Animal Ecology 69, 683-689.

Ruddock P.J., Bird D.J., McEvoy J., Peters L.D. (2003). Bile metabolites of polycyclic aromatic hydrocarbons (PAHs) in European eels Anguilla anguilla from United Kingdom estuaries. Science of the Total Environment 301, 105-117.

Scarlett A., Dissanayake A., Rowland S., Galloway T.S. (2009). Behavioural, physiological and cellular responses following trophic transfer of toxic monoaromatic hydrocarbons. Environmental Toxicology and Chemistry 28, 381-387.

Scarlett A., Donkin M.E., Fileman T.W., Donkin P. (1997). Occurrence of the marine antifouling agent irgarol 1051 within the Plymouth Sound locality: Implications for the green macroalga Enteromorpha intestinalis. Marine Pollution Bulletin 34, 645-651.

470 Scarlett A., Donkin P., Fileman T.W., Evans S.V., Donkin M.E. (1999). Risk posed by the antifouling agent Irgarol 1051 to the seagrass, Zostera marina. Aquatic Toxicology 45, 159-170.

Scott G.R., Sloman K.A. (2004). The effects of environmental pollutants on complex fish behaviour: integrating behavioural and physiological indicators of toxicity. Aquatic Toxicology 68, 369392.

475 Smallegange I.M., Van der Meer J. (2003). Why do shore crabs not prefer the most profitable mussels? Journal of Animal Ecology 72, 599-607.

Smith V.J., Ratcliffe N.A. (1978). Host defence reactions of the shore crab, Carcinus maenas (L.), in vitro. J Mar Biol Assoc UK 58,

Thorpe K.E., Taylor A.C., Huntingford F.A. (1995). How costly is fighting? Physiological effects of sustained exercise and fighting in swimming crabs, Necora puber (L) (Brachyura, Portunidae). Animal Behaviour 50, 1657-1666.

Underwood A.J. (2005) Experiments in Ecology: Their logical design and interpretation using analysis of variance. In. Cambridge University Press, Cambridge

van der Oost R., Vanschooten F.J., Ariese F., Heida H., Satumalay K., Vermeulen N.P.E. (1994). Bioaccumulation, biotransformation and DNA-binding of PAHs in feral eel (Anguilla anguilla) exposed to polluted sediments - a field survey. Environmental Toxicology and Chemistry 13, 859-870.

Watson G.M. (2004) Responses of the decapod crustacean, Carcinus maenas, following exposure to environmental contaminants. Development and application of multiple biomarkers. Doctor of Philosophy, University of Plymouth

Watson G.M., Andersen O.K., Galloway T.S., Depledge M.H. (2004). Rapid assessment of polycyclic aromatic hydrocarbon $(\mathrm{PAH})$ exposure in decapod crustaceans by fluorimetric analysis of urine and haemolymph. Aquatic Toxicology 67, 127-142.

Weis J.S., Samson J., Zhou T., Skurnick J., Weis P. (2001). Prey capture ability of mummichogs (Fundulus heteroclitus) as a behavioral biomarker for contaminants in estuarine systems. Can J Fish Aquat Sci 58, 142-1452.

Woodhead R.J., Law R.J., Matthiessen P. (1999). Polycyclic aromatic hydrocarbons in surface sediments around England and Wales, and their possible biological significance. Marine Pollution Bulletin 38, 773-790. 


\section{List of Figures}

Fig. 1 Location of field sites; Avon and Yealm ('comparatively clean') and Plym ('relatively' contaminated) (SW England, UK) (adapted from Amaral et al., 2009).

Fig. 2 Pyrene-type metabolites in the urine (mean \pm SE) of adult Carcinus maenas. ( $n=9$ per treatment, different letters indicate significant treatment differences).

Fig. 3 Cellular endpoints (mean \pm SE) evaluated in Carcinus maenas haemocytes. A) Cellular viability and B) Phagocytosis index. ( $n=9$ per treatment, different letters indicate significant treatment differences).

Fig. 4 Foraging behaviour (s) (mean $\pm \mathrm{SE}$ ) observed in adult Carcinus maenas.

A) breaking time of shelled-prey $\left.\left(T_{\mathrm{b}}\right), \mathrm{B}\right)$ eating time of flesh $\left.\left(T_{\mathrm{e}}\right), \mathrm{C}\right)$ handling time $\left(T_{\mathrm{h}}\right)$ (breaking time + eating time) and D) cardiac activity during prey handling time (beats/minute). ( $n=9$ per group, different letters indicate significant treatment differences). 


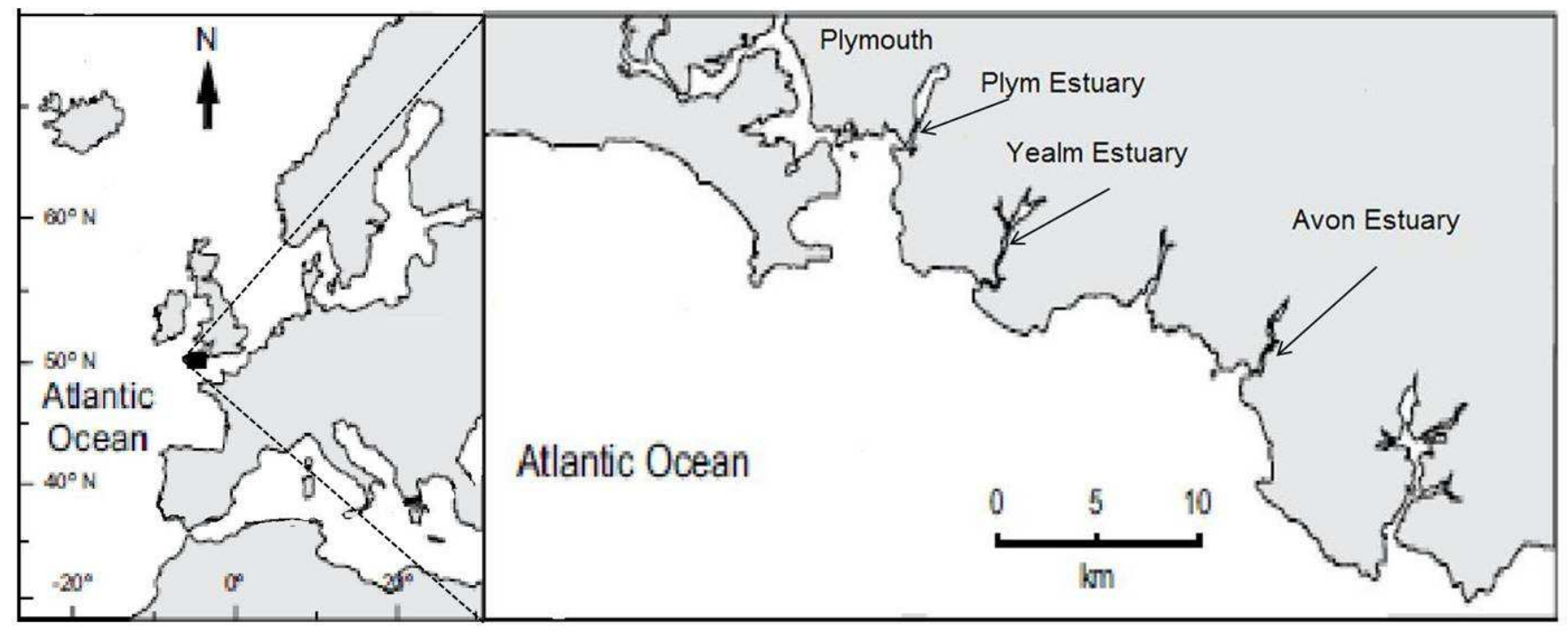

Fig. 1. 


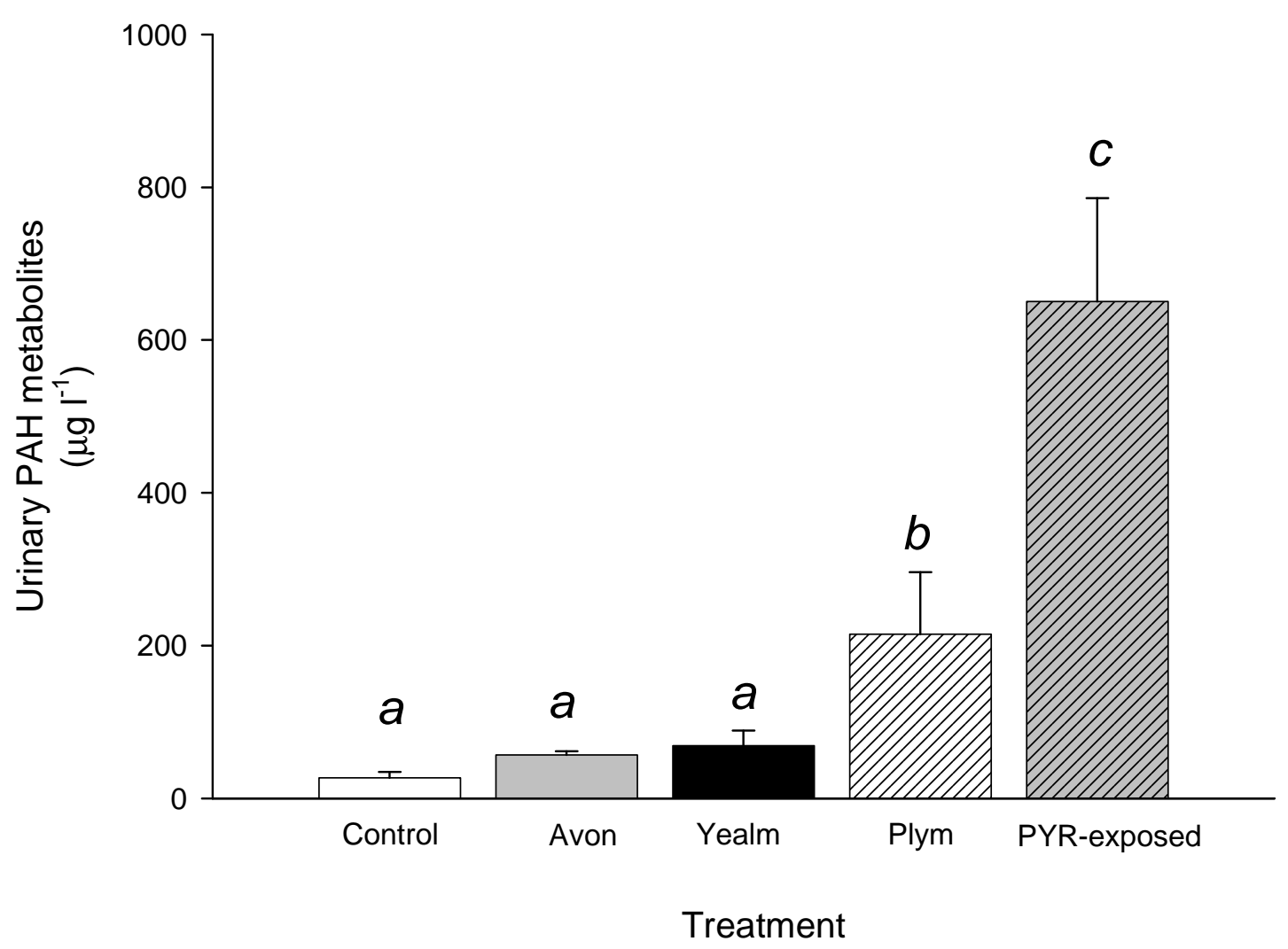

Fig. 2. 

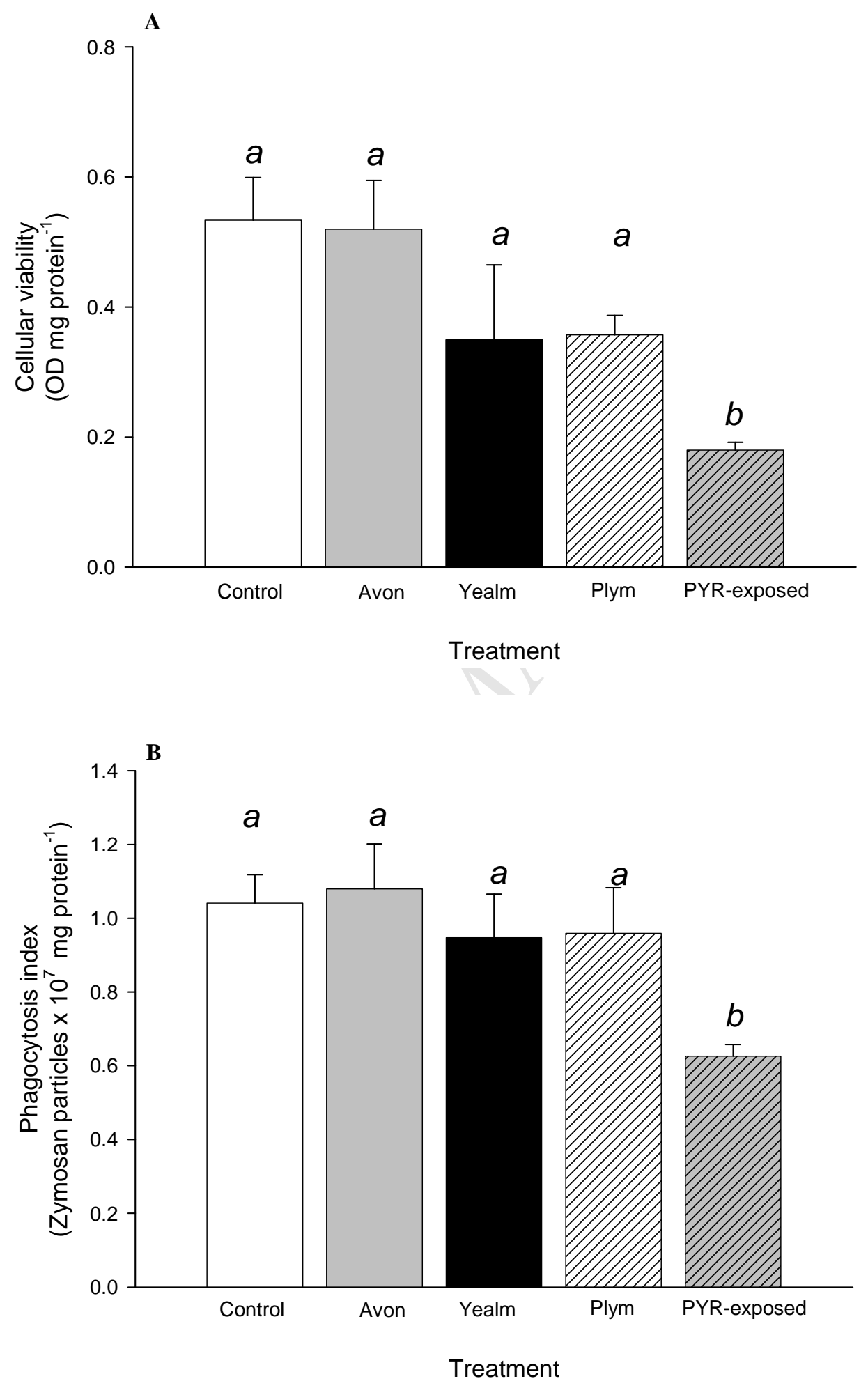

Fig. 3 


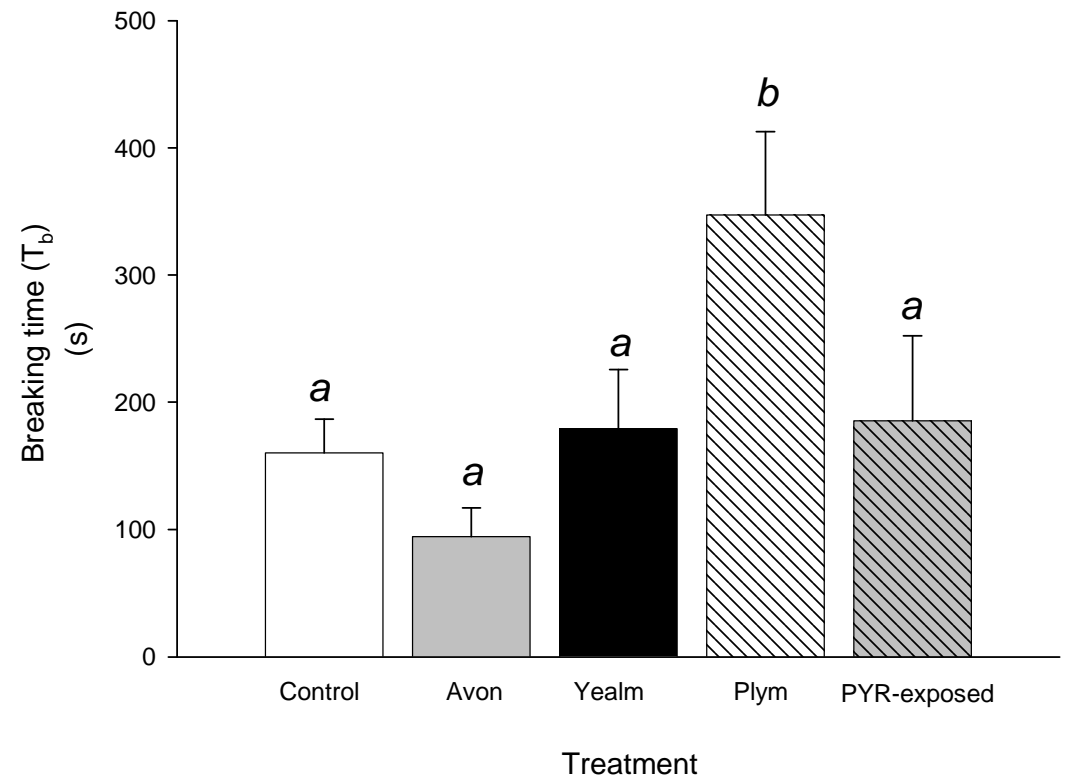

C

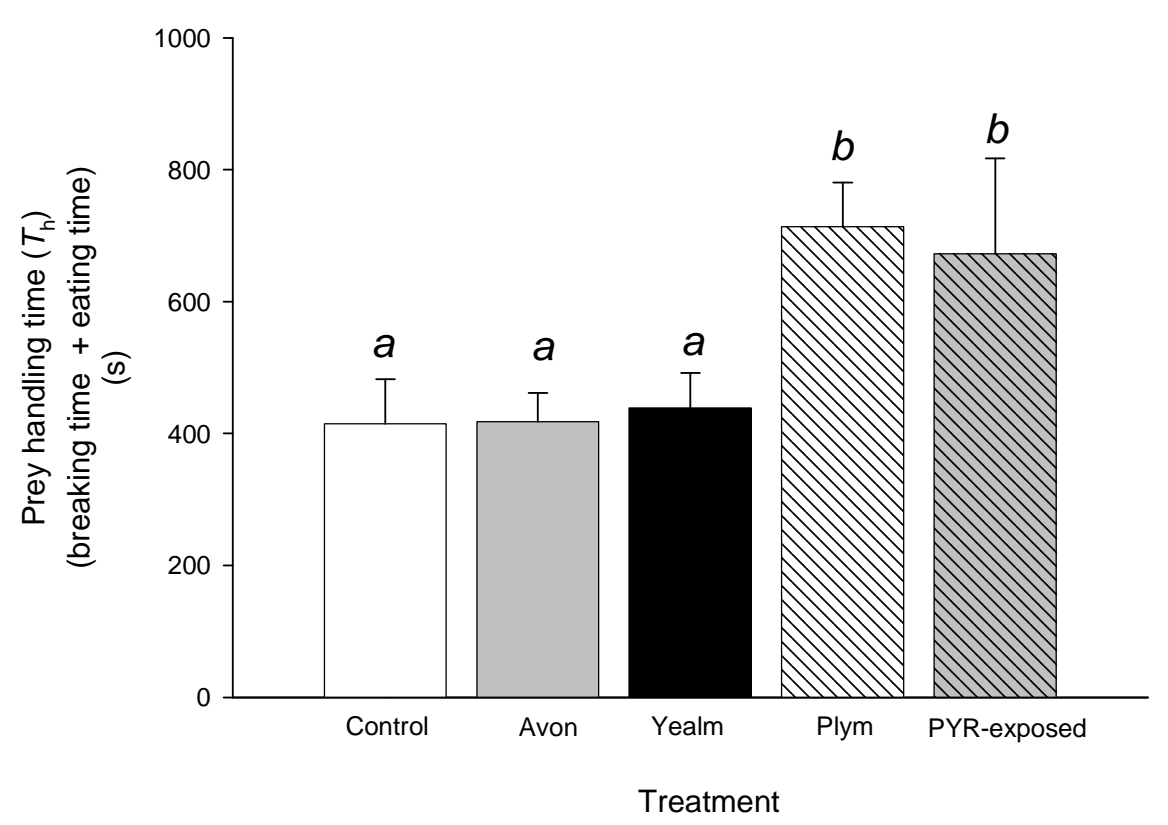

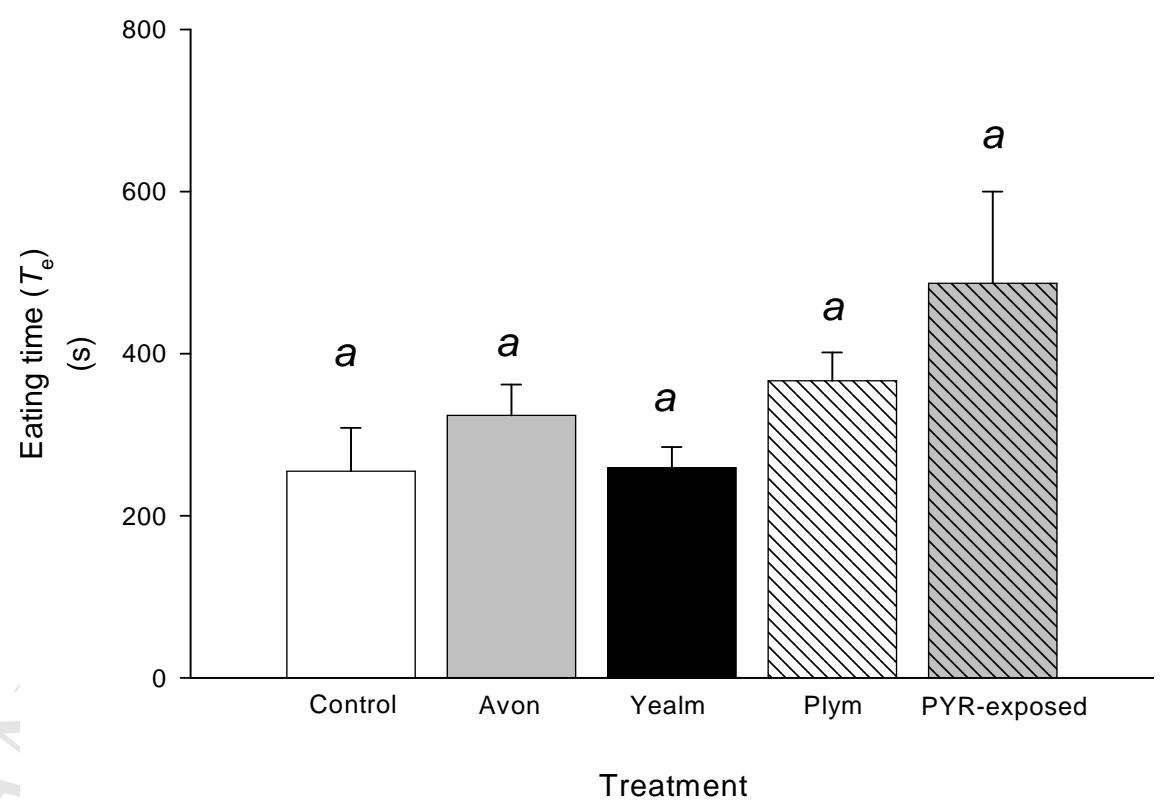

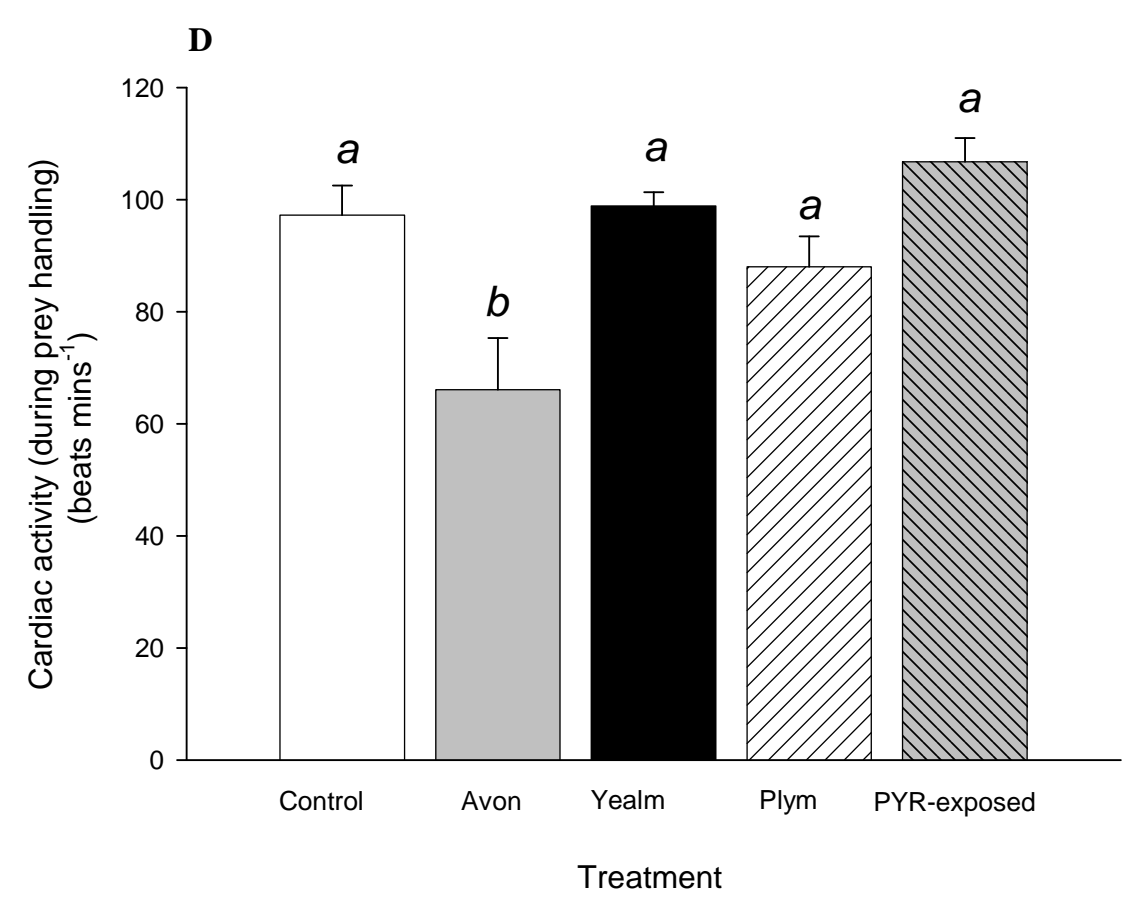

Fig. 4. 